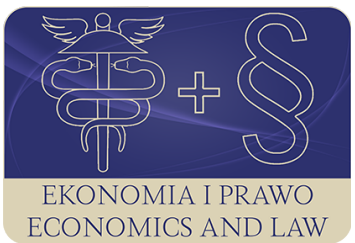

EKONOMIA I PRAWO. ECONOMICS AND LAW

Volume 18, Issue 4, December 2019

p-ISSN 1898-2255, e-ISSN 2392-1625

www.economicsandlaw.pl

ORIGINAL ARTICLE

received 14.09.2018; revised 21.09.2019; accepted 31.12.2019

Citation: Totleben, B., Szarzec, K., \& Kardziejonek, A. (2019). Rent-seeking by politicians in stateowned enterprises. Ekonomia i Prawo. Economics and Law, 18(4): 515-529. doi:10.12775/EiP.2019.034.

\title{
Rent-seeking by politicians in state-owned enterprises
}

\section{BARTOSZ TOTLEBEN}

corresponding author

Poznan University of Economics and Business, Faculty of Economics, Department

of Macroeconomics and Development Studies, al. Niepodleglości 10, 61-875 Poznań, Poland

$\square$ bartosz.totleben@ue.poznan.pl

(D) orcid.org/0000-0003-3187-2285

KATARZYNA SZARZEC

Poznan University of Economics and Business, Faculty of Economics, Department of Macroeconomics and Development Studies, Poland

$\square$ katarzyna.szarzec@ue.poznan.pl

(D) orcid.org/0000-0002-7675-2239

\section{ANDREAS KARDZIEJONEK}

Independent researcher, Poland

$\square$ andreas.kardziejonek@gmail.com

(D) orcid.org/0000-0002-8911-4770

\begin{abstract}
Motivation: Notwithstanding the privatization processes, state-owned enterprises (SOEs) continue to play an important role in Poland and other post-socialist countries. Governments declare that privatization is completed and that they do not intend to sell any more enterprises. They justify this by pointing to the national security and strategic sectors in which companies should remain state-owned. Unfortunately, SOEs are used by politicians for economic and personal rent-seeking.

Aim: This article aims to discuss the idea of economic rent-seeking by politicians, particularly its impact on SOEs. We claim that politicians, being a group of interest, capture SOEs in order to achieve private gains for themselves and their parties, which compromises economic performance of these companies. We analyze the mechanism of influence that politicians have on SOEs, including the processes related to rotations of managers
\end{abstract}


and boards of directors after winning parliamentary elections. To illustrate this, we analyze the scale of rotations in Polish SOEs in the years 2001-2017. The rotations are presented in absolute terms. Additionally, an index of the average number of changes in a company was estimated.

Results: We listed several examples of capturing SOEs by politicians. The number of SOEs in EU countries varies. Most SOEs are located in Germany and France. Among the countries of the post-socialist EU-11, Poland, Bulgaria and Romania have the most SOEs. The average number of rotations in personnel was significantly greater in SOEs than in private companies in Poland. Rotations in SOEs are positively correlated with political elections. The greatest increase in the number of changes in SOEs can be observed in the periods following parliamentary elections, regardless of which political party wins. This means that politicians treat SOEs as well-deserved spoils of victory and take it as their own.

Keywords: state-owned enterprises; rent-seeking; group of interests; rotations in management personnel

JEL: H82; L32; P31

\section{Politicians as a group of interest seeking economic rent}

The phenomenon of rent-seeking is defined as the natural pursuit of economic entities, in particular individuals, managers of enterprises and organisations as well as interest groups, to collect economic rent. Tullock (1967), who first made an attempt to describe the phenomenon of rent-seeking (without naming the concept), pointed to the existence of significant social costs associated with the establishment of monopolies and introduction of customs duties. He also noticed that creating such rents leads to a waste of resources due to an inefficient use of production factors. The concept itself was first introduced by Krueger (1974) who showed that even in free market economies, the ruling party affects economic processes with the law they pass, thus, interfering with the market mechanism to a certain extent. Consequently, rent-seeking relates to the rents created by the state as well as the entities that compete to capture them. State regulations which generate economic rents may be the result of an erroneous decision, changes in economic circumstances and pressures from various interest groups. An interest group is a collection of entities with common objectives and interests. These may be entities operating in the same industry or region, people with similar political preferences and worldview, etc. Interest groups - due to their ability to take collective actions - might have a real impact on the decisions made by the government ${ }^{1}$ (Olson, 1965). The state, which has a monopoly on coercion and sanctions, defines the scope of economic freedom and, therefore, becomes the target of interest groups which aim to change the existing regulations to meet their specific interests (Wilkin, 2016, p. 228).

Krueger (1974) observes that rent-seeking may take legal and illegal forms. Legal forms of rent-seeking include entities attempting to create a monopoly and improve their position, as well as lobbying. The latter involves individuals

${ }^{1}$ Olson (1965) distinguishes between interest groups capable of taking collective actions and unorganized groups that refrain from political activity (inactive groups). 
or groups of interests persuading lawmakers to support their agenda. It is important to note that lobbying includes only legal (in accordance with applicable law) techniques and methods (Piwowar \& Świeca, 2010). Illegal activities that lead to economic rents are: bribery, serious corruption consisting in buying favourable legal solutions that create rents, smuggling and illegal trade in goods and services. In the last case, rent-seeking is in fact a specific transaction on the verge between the economic and political worlds, where the demand side consists of individuals and interest groups while the supply side are the politicians 'selling' legal regulations in return for some benefits. This is an example of what Bhagwati (1982) calls 'directly unproductive profit-seeking activities', i.e. actions that do not lead to the creation of new products or services but bring cash benefits.

Taking into consideration how they were created, rents can be divided into artificial rents and real rents. Artificial rents are created in the course of decision-making by the government and are not the result of manufacturing processes; real rents, on the other hand, are the result of market competition (Atkan, 2015). The phenomenon of rent-seeking is in fact a pursuit of artificial rents that would not exist without the interference of political authorities in the market mechanism (Wilkin, 2012, pp. 229-234). Artificial rents interfere with the market mechanism by transferring income from some entities ('losers') to others (the 'winners', sometimes associated with the ruling party), mainly by means of influencing legal regulations. This results in the interception of income by unproductive entities or ones with low productivity.

Rents are created by the state, i.e. the governing bodies and politicians, and 'seeked' by individuals or interest groups. A specific interest group seeking economic rents could be politicians and appointed by them representatives in the executive branch of the government, even if they are elected in democratic parliamentary elections. They use their political position to obtain additional benefits which they would not have if not for the posts that they hold in the government. There are two main ways in which politicians could seek rent. Firstly, when politicians affect market conditions by means of regulations, thus, creating economic rents to satisfy interested entities or for the benefit of the politicians themselves ${ }^{2}$. Politicians as individuals can benefit from taking bribes, hiring relatives in state-owned enterprises, obtaining grants for parties or non-governmental organisations of their choice, etc. Secondly, politicians themselves can become involved in the market game. In this case, there are three situations in which politicians seek rent. First of all, if a politician is the owner of a private company, he might be tempted to propose that such laws be passed which would be beneficial for the industry in which his firm operates or to use the information he has access to before anybody else. Secondly, when there is a change in the legislative and executive bodies of the government and the people who had that power before go on to manage private enterprises ${ }^{3}$. Thirdly, politicians

2 E.g. so-called Rywingate in Poland.

${ }^{3}$ E.g. German chancellor Gerhard Schroeder, whose government accepted the con- 
can collect different kinds of economic rents from state-owned enterprises. After elections, SOEs are treated as well-deserved political spoils of victory. The following examples of using SOEs by politicians can be found:

offering positions in supervisory and management boards to people with political connections;

- a complete replacement of staff in management and supervisory boards before elections in order to receive high severance pays, and after having won parliamentary elections by the new ruling party;

- offering jobs in state enterprises to people associated with the ruling political party ${ }^{4}$ or their families;

- employing people associated with the ruling political party or their families in private companies that regularly provide services (e.g. in the consulting and marketing sector) to state-owned enterprises;

- increasing salaries in state-owned enterprises after winning parliamentary elections with no increases in productivity ${ }^{5}$;

- influencing the selection of private partners working with state-owned enterprises;

- influencing the choice of non-governmental organizations working with state enterprises and obtaining support from them or from the foundations established by them.

The effects of rent-seeking are negative. In the case of rent-seeking by politicians, the following results should be mentioned: corruption, falling under influences when passing regulations, nepotism and cronyism, as well as limiting access to economic and political processes.

Considering the informal nature of these phenomena and the fact that they cannot be readily tracked, it is difficult to quantify them. However, attempts to create indices that measure the scale of these phenomena have been made. One of them is the Corruption Perceptions Index (created by Transparency International (2018)), which is based on surveys that measure the subjective perception of corruption levels by analysts, experts and people involved in business.

Chart 1 shows the values of the Corruption Perceptions Index in the years 1995-2017. The index takes values from 0 to 10 and the greater its value, the less corruption phenomena there is in a country. The scope includes the European Union countries which are divided into two subgroups: (1) the Member States which belonged to the Union before the year 2004 (EU-15) and (2) the post-socialist Member States that are a part of the EU (EU-11). In the EU-15 countries, the level of corruption is perceived as low and stable. In turn, in the 11 post-socialist countries, a systematic reduction of corruption can be observed;

struction of Nord Stream gas pipeline, having stepped down as Chancellor became the chairman of the board of Nord Stream.

${ }^{4}$ People who are members of political parties and hold high-paid positions in companies are required to make much higher membership payments than regular members.

5 Selected analyses of wages and productivity: Guasch \& Weiss (1982), Kuźmar (2017, pp. 103, 167-168). 
however, the distance to the EU-15 is still considerable. After the political transformation, the EU-1l countries are still struggling in this area. In Poland, a significant reduction in corruption has been observed (especially after joining the EU in 2004); notwithstanding this, the index is still lower than in the EU15 countries.

Another group of indicators that can be used to assess the scale of rent-seeking are the ones included in the Fragile State Index developed by The Fund for Peace (2018), such as Factionalized Elites (division of powers in the state ${ }^{6}$ ) and Group Grievance (evaluation of existing social divisions, e.g. unequal and unfair access to the market and political processes). The higher the values of the indicators, the lower the assessment of the phenomena.

The values of both indicators illustrate that there are still significant differences between the EU-11 and the EU-15. Both Factionalized Elites (chart 2) and Group Grievance (chart 3) are greater, which shows that these phenomena are viewed better in the EU-15 countries. In the case of Poland, the assessment of the division of powers is stable; however, a significant decrease in the Group Grievance indicator can be observed. In 2018, for the first time in history, the value of this indicator was higher than the average for all the post-socialist countries. This shows that the threat of the negative effects of rent-seeking is growing.

In the case when politicians take over SOEs, the following negative effects can be observed: an increase in the rotations in management positions which is linked to the electoral cycle, lower standards of corporate governance, lower qualifications of people managing the businesses, higher labour costs (due to a growth in the rotations of personnel and severance pays). All of them contribute to lower financial efficiency of such companies compared to private firms (Szarzec et al., 2017). Many studies show that the efficiency of state enterprises is positively influenced by the introduction of corporate governance, good management, the existence of good economic and political institutions. In particular, as indicated by Bortolotti et al. (2013) and Borghi et al. (2016), there is a correlation between the efficiency of SOEs in network industries and the quality of political and economic institutions. Good state institutions, high standards of corporate governance, rotations in managerial staff determined by financial results and not political elections, allow to achieve better economic results. The main recommendation of numerous reports published by international organizations is that the negative effects associated with politicians having an impact on companies should be limited (e.g. OECD, 2010, 2015a, 2015b, 2015c).

\section{State-owned enterprises in national economy}

State ownership in enterprises has been discussed since the 1990s. Despite the waves of privatization, the state has remained a significant owner of enter-

${ }^{6}$ In extreme cases, it can show the absence of legitimate leadership that is widely accepted as representative of all citizens. 
prises in many countries. Moreover, the economic importance of state-owned enterprises on the global and regional markets has increased. A lot of SOEs have transformed their mode of operation: from a company with average efficiency and oriented mostly towards the domestic market, to one with high/growing efficiency and active on international markets. This has been mostly the result of changing institutions and establishing modern corporate governance.

The OECD (2005) has come up with a list of commonly stated reasons for state ownership. SOEs can:

- provide public goods;

- increase access to public services;

- generate public funds;

- improve labour relations, particularly in ,strategic' sectors;

- limit foreign control in the domestic economy;

- encourage economic development and industrialisation;

- be used as a crisis response tool in instances where events threaten the survival of companies deemed 'too big' or 'too strategic' to fail.

In the EU-28, the degree of state ownership varies, which results from historical conditions and the ownership policy of the country. Chart 4 shows the number of SOEs (05.2018) based on the Amadeus database (Bureau van Dijk, 2018). State-owned enterprises are defined in different ways (Battowski \& Kozarzewski, 2016). We used the classification of state-owned enterprises based on ownership structure. Majority state-owned enterprises are defined as entities in which the state holds directly or indirectly an ownership stake of more than $50 \%$ (SOE-50). The minority state-owned group consists of enterprises with an ownership stake of more than 25\% (SOE-25). In order to determine the ownership status of enterprises, ownership structures were checked using the Amadeus (Bureau van Dijk, 2018). We cover all NACE sections excluding: 'M. Professional, Scientific and Technical Activities', 'Public Administration and Defence'; 'Compulsory Social Security', 'P. Education', 'Q. Human Health and Social Work Activities'.

The most SOEs are located in Germany (6 415 SOE-25 and 5766 SOE-50) and in France (3 217 and 1956 respectively). Among the EU-11, the most SOEs can be found in Poland (2 626 SOE-25, i.e. $37.27 \%$ of the whole group), as well as in Bulgaria and Romania (approx. 14\% each).

SOEs are dominant in the natural resources, energy supply and transport sectors (European Commission, 2016; Szarzec \& Nowara, 2017). Also Kowalski et al. (2013) note that mining, extraction of crude petroleum and gas and transportation are sectors with the highest state share in the group of the world largest companies. As governments argue, these sectors concern strategic resources necessary to maintain national security. Moreover, they provide essential services at lower prices in less competitive markets.

The state remains an important owner of enterprises in the CEE region by means of a dominant stake or non-ownership tools (Bałtowski \& Kozarzewski, 2016; Szarzec \& Nowara, 2017). Furthermore, in Hungary and Poland one can 
also observe a change in the ownership policy and a trend of re-nationalisation through share buyouts in previously privatised companies (the so-called ,reversal in the privatisation logic ,) and politicians using SOEs for political and personal rent-seeking (Bałtowski \& Kozarzewski, 2016; Szanyi, 2016).

When in a country there is a large degree of state ownership (hereinafter understood as the number of SOEs), and poor corporate governance, the threat of negative means of rent-seeking being used grows. This applies in particular to post-socialist countries, where state ownership is still significant, ownership supervision is weak and enterprises are treated as electoral spoils. Moreover, in those countries (in particular in Romania and Bulgaria) the quality of state institutions is low, thus, they are more exposed to the negative effects of rent-seeking by politicians (Piątek, 2016).

\section{Characteristics of staff rotations in state-owned enterprises in Poland}

In order to study rent-seeking by politicians, a unique database has been created. It includes information about all changes in management boards in jointstock companies registered in Poland. A change in a management board means any employment or dismissal of a person, both in the case of a board of directors as well as a supervisory board in a company. The data used in the study were taken from the National Court Register (2018), to which - according to Polish law - all changes in these bodies should be reported. The timeframe of the study covers the period from 2001 (when the National Court Register was created) to 2017. In total, the database contains 82776 original entries with 207 259 changes in 13081 joint-stock companies.

Next, based on the Amadeus database (Bureau van Dijk, 2018), the ownership structure of companies was determined and divided into private companies (POE) and state companies (SOE-25 and SOE-50). The Amadeus database contains information about 3704 Polish non-financial joint-stock companies. Then, sports clubs (where the rotation of personnel depends mainly on sports results not financial results) and companies in liquidation were excluded from the analysis. The remaining companies were manually checked for changes in ownership structure and those which were privatized or nationalized ${ }^{7}$ during the analyzed period were excluded as well. In the end, 3525 companies were analyzed, $3156 \mathrm{POE}$ and 369 SOE-25 (including 307 SOE-50). The number of active companies registered in the National Court Register (2018) from 2002 until 2017 is shown in chart 5.

In the analyzed period, there was an increase in the number of POEs. The number of state-owned enterprises grew until 2010 and then decreased

7 The data sources about ownership structure, privatization and nationalization: Ministry of Treasury of the Republic of Poland (2018), the Privatization Barometer dataset (2018) and the World Bank privatization dataset (2018). 
in the period between 2010 and 2014. Since then, the number of SOEs has remained stable.

During the analyzed period, in 3525 companies there were 112338 changes in management boards, of which 31995 took place in boards of directors and 80 343 in supervisory boards. The number and nature of the changes, taking into account the ownership structure of companies, are presented in the table l. An index of the average number of changes in a company was estimated as the average number of changes per 1 company in 1 month.

The absolute number of changes in POEs greatly exceeds the number of changes in SOEs. Nevertheless, when taking into account the number of active companies during the analyzed period, the average number of rotations was significantly greater in SOEs (the average number of changes in 1 company is 0.32) than in POEs (0.17). This means that the frequency of changes in SOEs is about $86 \%$ higher than in POEs. Regardless of the ownership structure of a company, changes are most often made in supervisory boards than in boards of directors. The rate of rotations of people who are a part of the management of SOEs is higher than in POEs (the frequency of changes in management boards is 69\% greater while in supervisory boards it is as much as $98 \%$ ).

Observing such significant differences, one should ask a question about the reasons for their occurrence. To this end, the average number of changes in each month during the research period was calculated and compared to the electoral cycle in Poland (see chart $6^{8}$ ).

The monthly average of the number of changes per $1 \mathrm{POE}$ is stable and varies between 0.07 to 0.38 , while the much larger amplitude can be observed in SOEs (it fluctuates between 0.10 and 1.11). Based on the average scale of rotations in management boards of SEOs in each term of Polish Sejm (lower house of parliament), it should be noted that the most changes take place in the period following general elections. At that time, the monthly average number of changes per 1 SOE exceeds 0.6, regardless of which political party wins. As stated by the former President of Poland Aleksander Kwaśniewski 'what has been done with the public media is unprecedented and will cost dearly in the future. The story of the Constitutional Tribunal and the independence of courts is similar. These are three serious accusations, because I am not accusing them (meaning: politicians from the party Law and Justice - own note) of having offered jobs in state-owned enterprises to their own people. I'm disgusted by it; however, under Polish conditions it has become a tradition (emphasis - authors). It was also done by PO (Civic Platform) and SLD (Democratic Left Alliance)' (Witwicki, 2018). There seems to be a sanctioned tradition of taking the spoils after winning the elections.

In most cases, there has also been observed an intensification of changes before elections. This can be explained by the fact that the dismissed 'own'

8 The Pearson correlation coefficient for the frequency of changes between SOE-25 and SOE-50 is more than 0.97 . The chart 6 shows only SOE-25 to present this relation in a clear way. 
employees receive severance pay, and the newly hired 'own' people will also be dismissed when another party wins the elections and then they will receive severance pay. An exception were the elections in 2011 when there were no major changes. The ruling party PO again got the most votes and Donald Tusk remained Prime Minister for the second term. The ruling party probably predicted they would win.

Based on the data, it can be concluded that there exists a correlation between the rotations in management boards of SOEs and political elections in Poland. Politicians take over SOEs and this indicates that they are seeking economic rent.

\section{Conclusions}

Rent seeking is a part of any democratic market economy in which economic freedom is determined by the state. Economic rents can be captured by single entities or interest groups, including politicians. The latter can collect rents by creating laws that affect the economic conditions or participating in the market game. This can be seen when politicians use state-owned enterprises in different ways, which is particularly characteristic of post-socialist countries.

Based on the data from the National Court Register (2018), we claim that there exists a correlation between the rotations in management boards of SOEs and political elections in Poland. Every political election was followed by a change in personnel in management boards and supervisory boards. Political parties would take over SOEs, treating them as the spoils of the election. Such changes generate high costs, not only financial, related to severance pays of dismissed employees. Among them are the costs associated with the loss of experienced personnel, discontinuation of the implementation of projects, sudden changes in management strategies and long-term investment plans, employment of people with lower qualifications but associated with the ruling political party. These lead to lower financial results, lower competitiveness, and also cause uncertainty, not only in the enterprise itself, but also among entities that cooperate with the company.

The question remains why in Poland such major changes in SOEs take place after every political election. Why, despite the fact that so many years have passed since the economic transformation and entry into the EU, the Polish government continues to treat them as well-deserved political spoils. Moreover, there is the political and social acceptance that the Polish President mentioned.

\section{References}

Atkan, C.C. (2015). Political corruption: an introductory study on terminology and typology. International Journal of Social Sciences and Humanity Studies, 7(1). 
Bałtowski, M., \& Kozarzewski, P. (2016). Formal and real ownership structure of the Polish economy: state-owned versus state-controlled enterprises. Post-Communist Economies, 28(3). doi:10.1080/14631377.2016.1196885.

Bhagwati, J.N. (1982). Directly unproductive, profit-seeking (DUP) activities. Journal of Political Economy, 90(5). doi:10.1086/261104.

Borghi, E., Del Bo, C., \& Florio, M. (2016). Institutions and firms' productivity: evidence from electricity distribution in the EU. Oxford Bulletin of Economics and Statistic, 78(2). doi:10.1111/obes.12087.

Bortolotti, B., Cambini, C., \& Rondi, L. (2013). Reluctant regulation. Journal of Comparative Economics, 41(3). doi:10.1016/j.jce.2012.12.003.

Bureau van Dijk. (2018). Amadeus database. Retrieved 31.05.2018 from https:// amadeus.bvdinfo.com.

European Commission. (2016). State-owned enterprises in the EU: lessons learnt and ways forward in a post-crisis context. Institutional Paper, 031. doi:10.2765/99224.

Fund for Peace. (2018). Retrieved 20.05.2018 from https://fundforpeace.org.

Guasch, J.L., \& Weiss, A. (1982). An equilibrium analysis of wage: productivity gaps. The Review of Economic Studies, 49(4). doi:10.2307/2297282.

Kowalski, P., Büge, M., Sztajerowska, M., \& Egeland, M. (2013). State-owned enterprises: trade effects and policy implications. OECD Trade Policy Papers, 147.

Krueger, A. (1974). The political economy of the rent-seeking society. The American Economic Review, 64(3).

Kuźmar, S. (2017). Determinanty regionalnej wydajności pracy w Polsce w latach 1995-2013. Warszawa: Difin.

Ministry of Treasury of the Republic of Poland. (2018). Retrieved 20.05.2018 from http://msp.gov.pl.

National Court Register. (2018). Retrieved 20.05.2018 from https://ems. ms.gov.pl.

OECD. (2005). OECD guidelines on corporate governance of state-owned enterprises. doi:10.1787/9789264009431-10-en.

OECD. (2010). Accountability and transparency: a guide for state ownership. doi:10.1787/9789264056640-en.

OECD. (2015a). OECD guidelines on corporate governance of state-owned enterprises. doi:10.1787/9789264244160-en.

OECD. (2015b). State-owned enterprise governance: a stocktaking of government rationales for enterprise ownership. doi:10.1787/9789264239944-en.

OECD. (2015c). State-owned enterprises in the development process. doi:10.1787/9789264229617-en.

Olson, M. (1965). The logic of collective action: public goods and the theory of groups. Cambridge: Harvard University Press.

Piątek, D. (2016). Instytucje państwa a wzrost gospodarczy w krajach postsocjalistycznych. Poznań: UE w Poznaniu. 
Piwowar, B., \& Świeca, J. (2010). Lobbing: biznes, prawo, polityka. Warszawa: Poltext.

Privatization Barometer. (2018). Retrieved 20.05.2018 from http://www.privatizationbarometer.com.

Szanyi, M. (2016). The reversal of the privatisation logic in Central European transition economies. Acta Oeconomica, 66(1). doi:10.1556/032.2016.66.1.2.

Szarzec, K., \& Nowara, W. (2017). The economic performance of state-owned enterprises in Central and Eastern Europe. Post-Communist Economies, 29(3). doi:10.1080/14631377.2017.1316546.

Szarzec, K., Nowara, W., \& Żurek, M. (2017). Forma własności a wyniki ekonomiczne największych przedsiębiorstw krajów Europy Środkowo-Wschodniej. Gospodarka Narodowa, 289(3). doi:10.33119/gn/100746.

Transparency International. (2018). Retrieved 20.05.2018 from https://www. transparency.org.

Tullock, G. (1967). The welfare costs of tariffs, monopolies and theft. Economic Inquiry, 5(3). doi:10.1111/j.1465-7295.1967.tb01923.x.

Wilkin, J. (2012). Pogoń za rentą za pomocą mechanizmów politycznych. In J. Willkin (ed.), Teoria wyboru publicznego: gtówne nurty i zastosowania. Warszawa: Scholar.

Wilkin, J. (2016). Instytucjonalne i kulturowe podstawy gospodarowania: humanistyczna perspektywa w ekonomii. Warszawa: Scholar.

Witwicki, P. (2018). Aleksander Kwaśniewski: robienie polityki przez Twittera to szaleństwo. Retrieved 31.05.2018 from http://www.rp.pl.

World Bank. (2018). Retrieved 20.05.2018 from https://data.worldbank.org.

\section{Acknowledgements}

Author contributions: authors have given an approval to the final version of the article. Authors contributed to this work equally.

Funding: this research was fully funded by a grant (2015/17/B/HS4/00327) from National Science Centre Poland.

Note: the results of this study were presented at Second Scientific Conference Institutions: theory and practice (June, 19-20, 2018, Torun, Poland). 


\section{Appendix}

Table 1.

The characteristics of rotations in management personnel 2001-2017

\begin{tabular}{|c|c|c|c|}
\hline \multirow[b]{2}{*}{ Ownership structure } & \multirow{2}{*}{$\begin{array}{c}\text { Privately-owned } \\
\text { POE }\end{array}$} & \multicolumn{2}{|c|}{ State-owned } \\
\hline & & SOE-25 & $\begin{array}{l}\text { including: } \\
\text { SOE-50 }\end{array}$ \\
\hline the number of observations (in company-montha ${ }^{\text {) }}$ & 503780 & 75479 & 61048 \\
\hline the total number of changes in management boards & 87845 & 24493 & 19814 \\
\hline \multirow{2}{*}{ including: board of directors } & 11730 & 2970 & 2394 \\
\hline & 13872 & 3423 & 2761 \\
\hline \multirow{2}{*}{ including: supervisory board } & 30037 & 8919 & 7226 \\
\hline & 32206 & 9181 & 7433 \\
\hline the average number of changes ${ }^{\mathrm{b}}$ & 0.1744 & 0.3245 & 0.3246 \\
\hline \multirow{2}{*}{$\begin{array}{l}\text { in boards of directors } \\
\text { in supervisory boards }\end{array}$} & 0.0233 & 0.0393 & 0.0392 \\
\hline & 0.0596 & 0.1182 & 0.1184 \\
\hline
\end{tabular}

Notes:

a - the number of companies is expressed in company-month units (particular company in a particular month); ${ }^{\mathrm{b}}$ - the average number of changes per 1 company in 1 month.

Source: Own preparation based on the data in the National Court Register (2018).

\section{Chart 1.}

The value of the Corruption Perceptions Index in the years 1995-2017

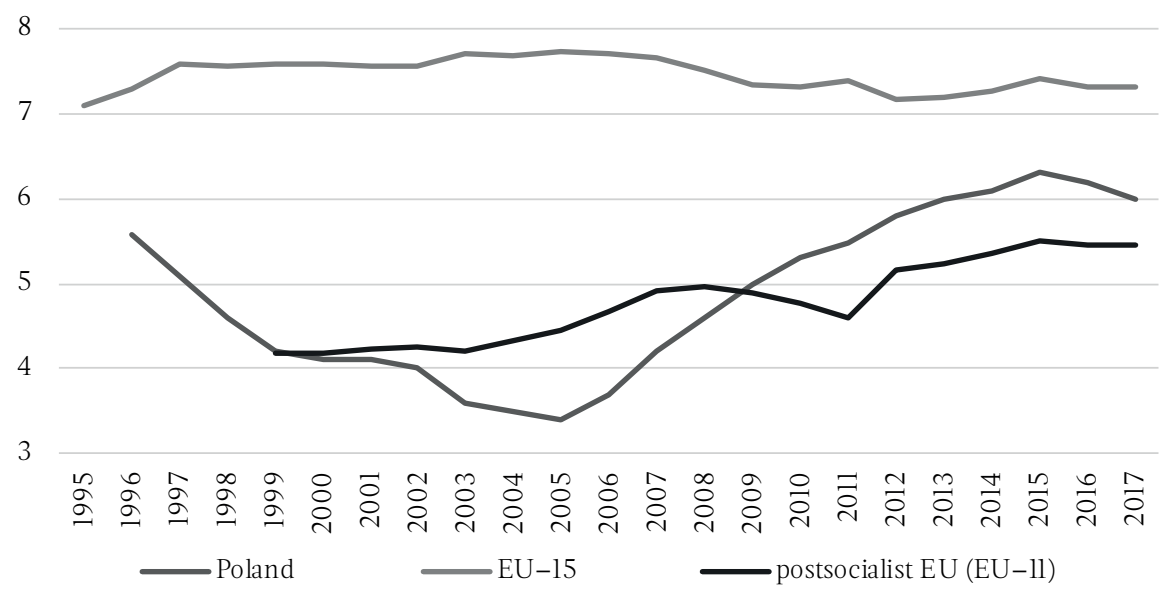

Source: Own preparation based on the data from Transparency International (2018). 


\section{Chart 2.}

The Factionalized Elites indicator in the years 2006-2018

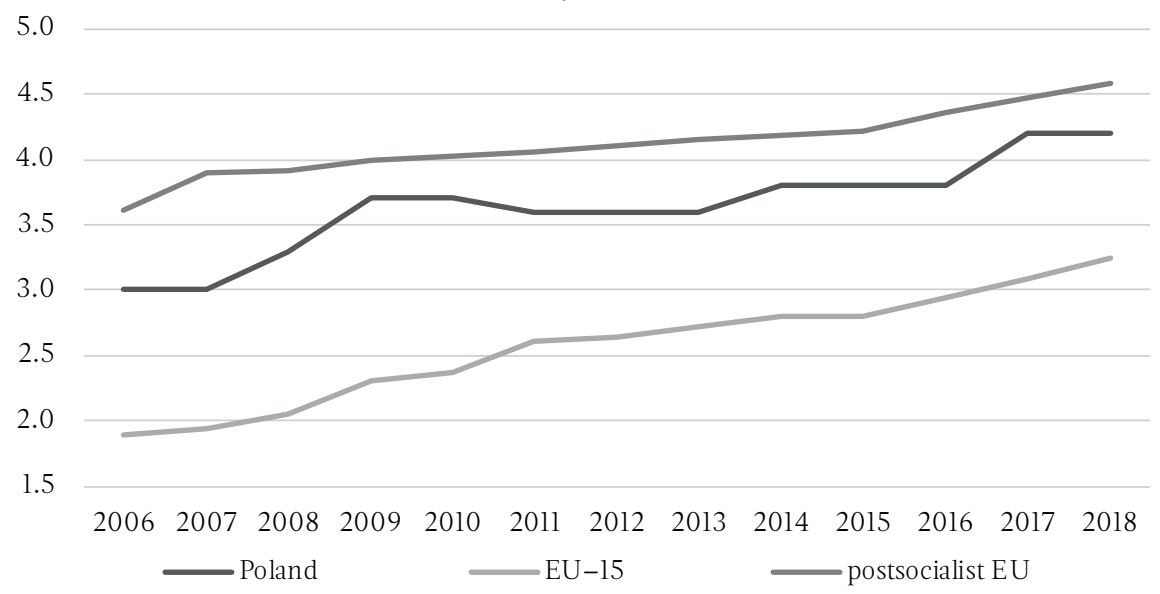

Source: Own preparation based on the data from Fund for Peace (2018).

\section{Chart 3.}

The Group Grievance indicator in the years 2006-2018

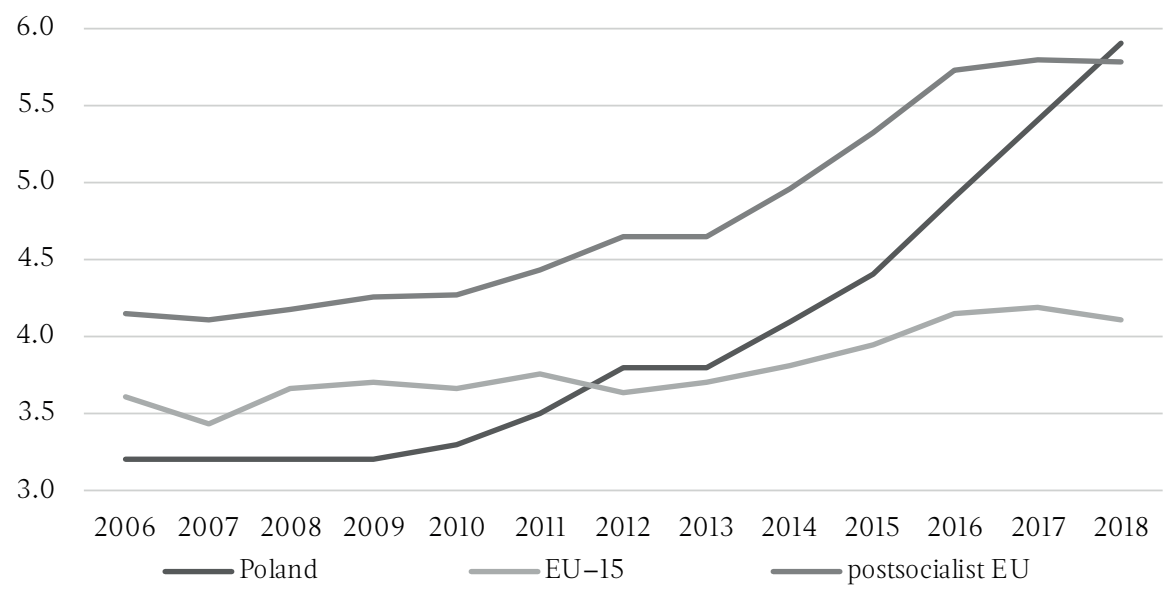

Source: Own preparation based on the data from Fund for Peace (2018). 


\section{Chart 4.}

The number of SOEs in the EU-28 in 2018

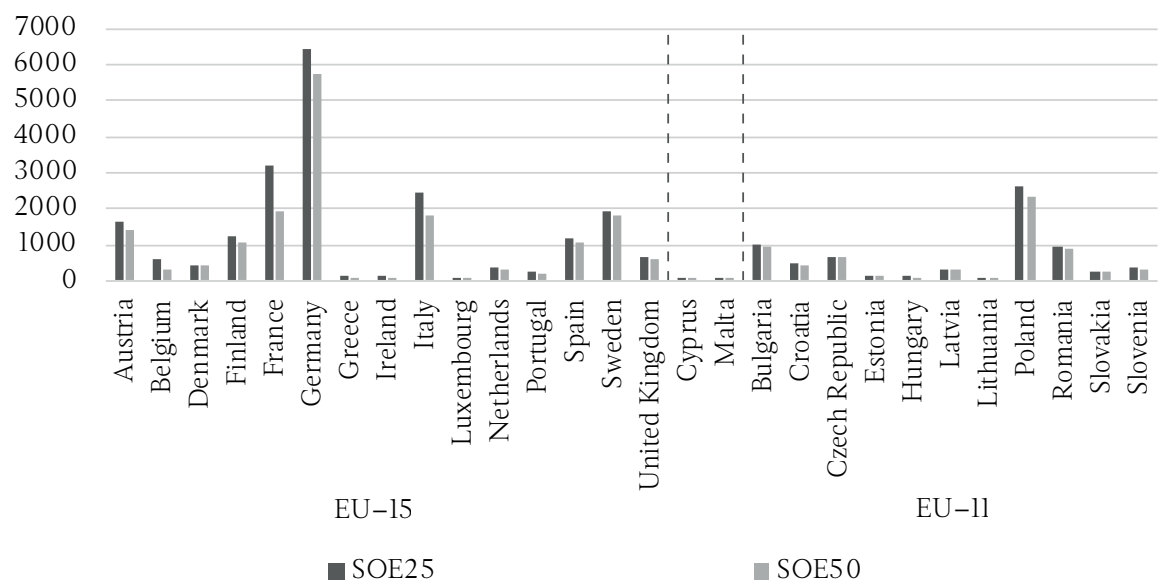

Source: Bureau van Dijk (2018).

\section{Chart 5.}

The number of active enterprises in the years 2002-2017

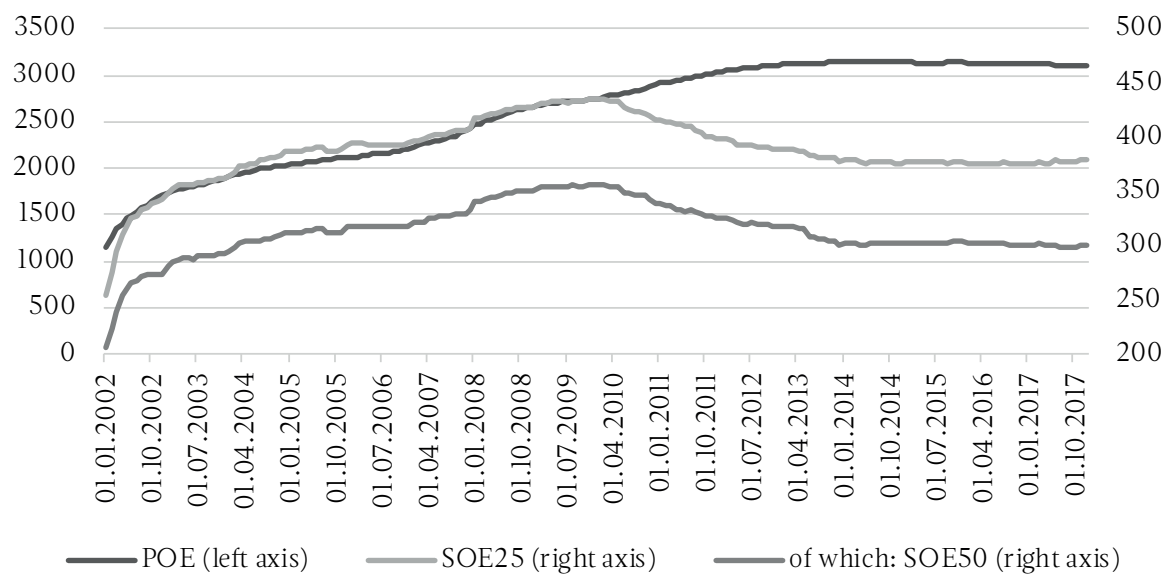

Source: Own preparation based on the data in the National Court Register (2018). 


\section{Chart 6.}

The average number of changes in management boards, and general elections in Poland in the years 2001-2017

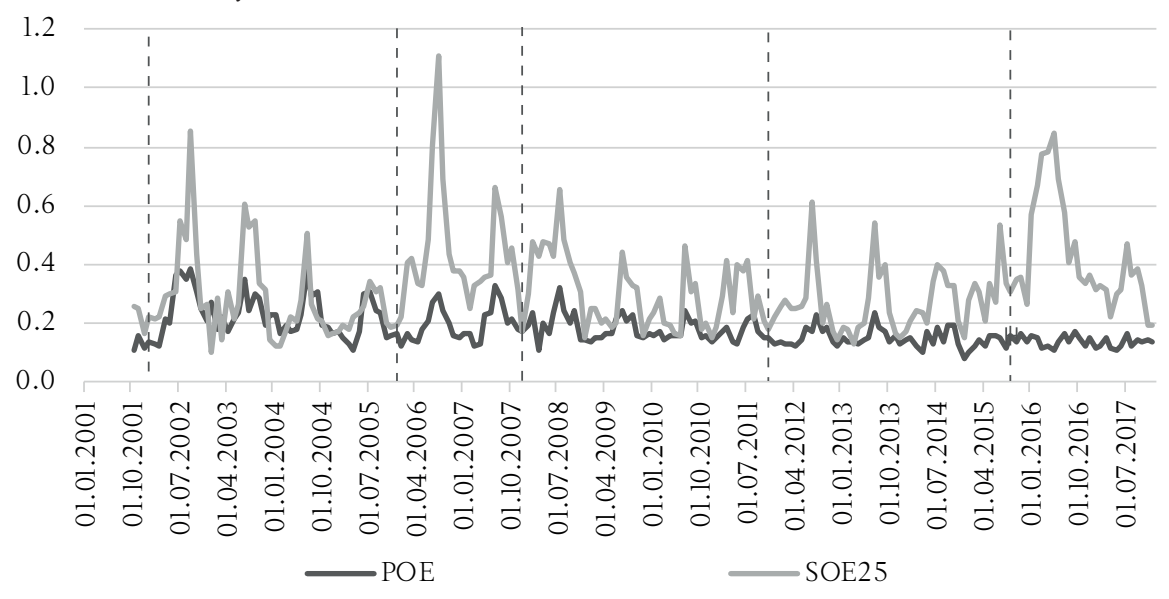

Note:

The gray dashed lines mark the date of general elections.

Source: Own preparation based on the data in the National Court Register (2018). 
